Article

\title{
Logistics Challenges in Sub-Saharan Africa and Opportunities for Digitalization
}

\author{
Damilola Kuteyi * and Herwig Winkler *(1)
}

Citation: Kuteyi, D.; Winkler, H. Logistics Challenges in Sub-Saharan Africa and Opportunities for Digitalization. Sustainability 2022, 14, 2399. https://doi.org/10.3390/ su14042399

Academic Editor: Armando Cartenì

Received: 13 December 2021

Accepted: 17 February 2022

Published: 19 February 2022

Publisher's Note: MDPI stays neutral with regard to jurisdictional claims in published maps and institutional affiliations.

Copyright: (C) 2022 by the authors. Licensee MDPI, Basel, Switzerland. This article is an open access article distributed under the terms and conditions of the Creative Commons Attribution (CC BY) license (https:// creativecommons.org/licenses/by/ $4.0 /)$.

\author{
Chair of Production and Operations Management, Brandenburg University of Technology, Siemens-Halske-Ring 6, \\ 03046 Cottbus, Germany \\ * Correspondence: kuteyidamilola@gmail.com (D.K.); winkler@b-tu.de (H.W.); Tel.: +49-178-1882289 (D.K.); \\ +49-355-694120 (H.W.)
}

\begin{abstract}
Improvements in logistics performance are considered to be a significant driver of economic growth. Digitalization in logistics, which includes enhanced tracking systems, digitized flows of information, artificial intelligence and automation, has further enabled globalized trade. However, Sub-Saharan African (SSA) economies, majorly export-commodity-dependent, still lag behind, grappling with inadequate policy frameworks, huge infrastructure deficits and trade barriers which result in a broken supply chain that negatively impacts growth. This study aims to investigate existing challenges in Sub-Saharan Africa, the potentials for the region to leapfrog traditional supply chain practices and adopt digital technologies, by evaluating previous findings in a systematic manner and augmenting these findings through semi-structured interviews. Systematic literature analysis conducted on published academic literature within a specific period and based on predefined criteria resulted in 287 articles being used for the final analysis. The most common logistics challenges and potential solutions have been identified. Semi-structured interviews with logistics service providers in the region have been conducted to establish the findings highlighted in the systematic literature review. The interviews showed that human capital training is a major factor when adopting digital technologies, and a focus on infrastructure investments, regulatory and institutional framework improvements will boost economic growth in Sub-Saharan Africa.
\end{abstract}

Keywords: digitalization; industry 4.0; logistics; sub-Saharan Africa

\section{Introduction}

Logistics performance is a strategic factor which indicates competitiveness of economies and businesses, and a catalyst for job creation and growth of the economy. The increased use of digital information technology in logistics management has resulted in enhanced competitiveness on global scales, by enhancing flow of information, planning, inventory control, packaging/handling, and transportation. Factors such as expanded operations across wider complex markets, changing business environments and customer requirements, faster speed of entry into market for new products and the need for responsiveness have made supply chains more economically vital, as well as volatile. Demand for digital solutions has been on the rise as the role of distributed ledger technologies, Industry 4.0 technologies and IoT-based cyber-physical systems (CPS) architecture to achieve sustainable productivity, profitability and performance is increasingly being embraced by organizations [1]. This has resulted in concepts such as digital supply chains (DSC) and Logistics 4.0 which are very dynamic and continuously evolve in their configuration, coordination and management-they have better visibility, higher consumer responsiveness and increased flexibility [2].

Research on African markets shows that the continent is emerging strategically as an important trading bloc particularly for Asia and parts of Europe, based on its vast resources, growing wealth and larger middle class with higher purchasing power [3] (p. 18). Freight 
transport in SSA faces many infrastructural and social challenges such as low intra-African collaboration/trade, bottle-necked port operations, expensive yet poor inland road quality, inadequate rail capacity, political and security instability, slow development in transportation and trade technology, and cultural differences [3] (p. 21). ICT implementation in several parts of Sub-Saharan Africa (SSA) is still considerably low, compared to international standards, as there exists a digital divide with large numbers of Africans in rural areas living with limited access to make a basic telephone call, while other regions (urban) are saturated with fast internet access and advanced digital telecommunication systems [4]. This gap is more readily pronounced in the wake of humanitarian crises, such as the COVID-19 pandemic, where inadequate access to digital tools has limited capacity for operational activities and humanitarian aid. These challenges have made Africa a difficult terrain for logistics business and limited the participation of big international companies by forcing them to adapt to local circumstances of informal economy, use costlier air transport instead of sea freight (to avoid the excessive port delays and reach landlocked countries with poor road networks) or maintain higher inventory volumes than anywhere else globally [3] (pp. 22-24).

This paper aims to address the above-mentioned issues by systematically reviewing published literature related to digitalization and logistics in SSA to ensure that identified challenges and potential solutions are adequately presented and can serve as a reference for logistics practitioners across the region to evaluate their operations and digitalization initiatives which may improve their strategic business decisions. It also aims to conduct a semi-structured interview with logistics service providers to compare with the results of the systematic literature review.

This study is developed in six sections. Section 1 introduces the research work and the aims of the study. Section 2 presents the methodology applied in this paper, including bibliometric results of a systematic literature research and a subsequent content analysis. An empirical investigation into the topic through semi-structured interviews has been presented in Section 3, while Section 4 contains the discussion of the results. The outlook and limitations of the study are presented in Section 5, and the conclusion is in Section 6.

\section{Systematic Literature Analysis}

\subsection{Methodological Approach}

This section aims to describe the process of the literature review. In this paper, a structured literature analysis was performed based on secondary-data-based evaluation of publications regarding logistics in Sub-Saharan Africa and digitalization of supply chains. Structured literature analysis involves content analysis which refers to an explicit definition of search criteria, search terms, databases used and publication period. It is regarded as a powerful and comprehensive tool based on its characteristic combination of qualitative and quantitative analyses [5]. Beginning with a thorough understanding of the research question and search, the seven steps shown in Figure 1 below have been used to perform the analysis.

A thorough understanding of the topic was used to determine keywords which can help to identify the logistics challenges existent in SSA as well as existent digitalization solutions. Through a preliminary search in selected databases, a few keywords were tested and optimized as necessary to measure relevance which was used for category selection and evaluation of materials. A subsequent search was then performed on peerreviewed journals and literature databases including Web of Science, Science Direct and Google Scholar using keywords (e.g., "logistic*”, "supply chain", "digital" , "technology*”, "Africa") to obtain all the documents that address the topic being investigated. For the descriptive analysis part, searches were limited to return articles only in the English language published between 1988 and 2021. This has been characterized below in the descriptive analysis section. From the literature titles and abstracts found, the relevance quality was assessed, and more adjustments were made as appropriate. Next, the filtered literature was analyzed and classified in detail. 


\begin{tabular}{|cl|}
\hline 1. & development of a thorough understanding of the topic \\
\hline 2. & $\begin{array}{l}\text { identification of two main topics, a subject area and subsequent } \\
\text { definition of keywords }\end{array}$ \\
\hline 3. & performing a preliminary research in selected databases \\
\hline 4. & performing the research in several available/suitable databases \\
\hline 5. & conducting a prior evaluation of the quality of the literature \\
\hline 6. & performing a detailed analysis and classification of the selected \\
\hline 7. & presenting the findings
\end{tabular}

Figure 1. Structure of the literature analysis conducted.

\subsection{Bibliometric Results from the Systematic Literature Research}

At this stage of literature analysis, the preliminary results for publications relevant to this research topic were filtered out manually from the total publications returned. The search was conducted between May-July 2021 on the Web of Science and Science Direct databases. In Emerald, less relevant publications were found on the issue of the digitalization of supply chain in Africa. Based on the multidisciplinary nature of digital supply chains, studies were difficult to confine to precise categories; hence, a broader bibliography for DSC was obtained by incorporating Google Scholar search queries. Publications considered included scientific publications, academic articles, industrial reports and white papers. Preliminary results from Web of Science were 1379 publications, while Science Direct returned 313 results.

Zotero, an open-source program, was used to organize and process the results. This was used to identify sources with keywords, to obtain bibliographic data, search through imported literature and check for duplicates.

Next, an analysis of the relevant literature and classification based on relevance was performed. The identified relevant papers covered several interrelated fields such as management science, food and agriculture (considering that a large percentage of logistics operations in the region involves food transport), operations and logistics. As for exclusion criteria, out of the relevant papers examined, only publications with material specific to logistics challenges or digital solutions were included in the final sample alongside other sources which could be accessed online. Research into logistics as part of digital supply chains only emerged as popular a few years ago; hence, there is still a significant research gap and paucity of relevant publications, particularly for developing economies such as in Sub-Saharan Africa.

This literature review indicates that as academic research interest in digitalization in logistics is increasing, industries and organizations have begun to see significant business cases for use of digital technologies and are now rapidly expanding their adoption. There is still a tangible gap between the academic literature and theory of logistics 4.0 and the practical application across industries especially in Africa. Only a few studies are centered on the concept of digital supply chains, but there are significantly more publications which discuss the enabling technologies and their applications. Thus, the majority of articles have focused on the technological enablers of digital supply chains. Publications on logistics in Africa are still considered to be narrow and restricted. There is a need for more recent and comprehensive reviews and scientific publications which would present a structured, statistically accurate analysis of supply chain management across the regions.

For studies focused on supply chain management in Africa, there were only four articles identified which were published between 1988 and 2000, 35 were published between 2001 and 2011, and 137 papers from 2012 to July 2021. Authorship, however, is diverse, as several researchers around the world are interested in research on supply chain management and logistics in Africa. Most of the identified research in Africa favors the 
operational activities in logistics and SCM and performance of product-specific supply chains and improvement strategies. For this research, among the relevant publications identified, a total of 20 papers (6.96\%) were published between 1988 and 2000, 81 papers (28.2\%) between 2001 and 2011, and 186 papers (64.8\%) between 2012 and July 2021. Overall, there is an increase in number of relevant research and publications in the area of digital supply chains and to a lesser degree, the application of digital technologies logistics in Sub-Saharan Africa.

Ivanov et al. [6] discussed the digital technologies supporting the digitalization of supply chain and operations management based on the SCOR model and how they influence decision-making. Souza et al. [7] characterized the digital supply chain in their 2021 paper, making a consideration for application of smart technologies and the frameworks provided in the current literature. They proposed that companies and organizations should approach their supply chain activities with new perspectives which consider these continually emerging technologies and their application to guarantee efficiency, flexibility and sufficient integration of their value chains in a digital world.

For logistics and supply chain management systems in Sub-Saharan Africa, the book Business in Africa in the Era of Digital Technology presents a broad overview of the impact of digital technologies on business in Africa and has a dedicated chapter that investigates the barriers in SCM systems in Africa and factors driving collaboration in selected regions [8] (p. 123). Logistic challenges and barriers to efficient supply chain management were also well discussed, in particular, the transportation infrastructure and inefficient port systems which significantly hamper development in logistics and trade across SSA.

Industrial and economic development reports were also examined, particularly to understand the application of DSC in the context of Sub-Saharan Africa. The World Bank presented in its 2019 report [9] (p. 4) that digital technologies can significantly improve food systems efficiency and environmental sustainability in Africa, improving competitiveness especially for small-scale producers, reducing costs for markets, information asymmetry and improving public services. Recent reports by the World Bank [10] also presented country diagnostic evaluations of selected regions in Sub-Saharan Africa, highlighting the present challenges as well as solutions available from implementation of digital technologies.

The African Continental Free Trade Area (AfCFTA) agreement was also well discussed in a new report by the World Bank [11] (p. 11) highlighting the predicted economic and developmental impacts across several regions, as well as the implications for poverty reduction, growth, trade and employment.

\subsection{Content Analysis of the Systematic Literature Review}

\subsubsection{Logistics Realities in Sub-Saharan Africa}

Africa is a continent with over 900 million people across 54 countries [12] (p. 65). Africa's merchandise export contribution to the global market has steadily declined since 1948 from $7.3 \%$ to about $2.2 \%$ in 2016 [13], which is remarkably poor considering the wealth of natural resources and agricultural products which are abundant in the continent. There are two main regions in Africa-the Middle East and North Africa, and secondly, SubSaharan Africa (SSA). SSA is endowed with vast amounts of resources including diamonds, crude oil, gold and agricultural products; yet it is the only region with a dramatic increase in the world's poorest population.

Two reasons are highlighted for this low trade performance-firstly, a predominant focus on international export of a few commodities (fuel, agricultural produce and mining products); secondly, supply chain and logistics difficulties across the region. A number of multinational firms that have been expanding into other emerging markets have found it difficult to penetrate SSA as the supply chain and logistics costs are too high. Thus, it is a strategic competitive priority for organizations that do, or wish to do business in Africa, to understand the present condition of logistics and SCM practices in Africa and identify the challenges and opportunities to succeed. 
Economic fragmentation is high in Africa and intra-regional trade is significantly higher in other regions-67\% in Europe, 58\% in Asia, 48\% in North America and Latin America, 20\% in the Caribbean, 16\% in Africa [14]. This low trade has been attributed to several factors including excessive tariffs, non-tariff barriers, regional conflict, corruption, poor logistical infrastructure and so on. Non-tariff barriers include measures such as price control (multiple exchange rates, foreign exchange allocation), monopolies, customs procedures and regulations, quotas, subsidies, anti-dumping or countervailing measures [15]. Studies have shown that spatial inequality has a tangible consequence on economic development, and the urban agglomeration of economic activity in a country determines the country's economic development pattern; however, many African countries rely heavily on single commodities as their main export (e.g., Crude oil in Nigeria, Platinum in Zimbabwe, etc.). Several studies have shown that while exports are good for growth [16] (p. 178), the important factor is not how much goods are exported, but the type of goods which are exported. Regions in developing countries with lesser specialization and a wider diversification of exports have been found to experience increased GDP per capita and higher rates of economic growth [15].

Stiff regulatory environments are also very common in sub-Saharan African countries as most of them not having enabling regulations or policies for customs processes, logistic infrastructure, transportation, business practice. A transport policy review focused on road, port and maritime traffic, rail and corridor transit conducted across six countries in SSA revealed that the little progress recorded across these regions over the past two decades was still due to policies made in the 1990s [17] (p. 53). The Nigerian Government in 2019 decided to close its land borders with neighboring countries including Benin, Cameroon, Niger and Chad, in a bid to curb smuggling which is already prevalent due to import restrictions, thereby effectively blocking the legal movement of goods. After significant increase in inflation due to food prices, and without any tangible proof of effective results [18], the government had to partially lift the closure in December 2020.

Industrialization in Africa over the past 50 years has been very disappointing. Average share of manufacturing in GDP across sub-Saharan Africa in the 1970s was 10 percent and as of 2010 remained unchanged, while the share of global manufacturing has fallen from about 3 percent in 1970 to less than 2 percent in 2010 [19], yet transport prices in SSA are very high compared with other regions, particularly for landlocked countries in Africa which have expensive transport costs. One study estimated that road transport was up to 40 percent higher in Cameroon, Mali and Cote d'Ivoire than in France (which has higher labor rates) and up to six times more expensive than it is in Pakistan [20].

\subsubsection{Logistics Challenges Evaluated Per Region}

Logistics infrastructure suffers significantly across sub-Saharan African regions, limiting the smooth and efficient flow of cargo between different countries. The state of infrastructure is described as follows.

\section{West and Central Africa}

West Africa's trade flows are carried on a network of eight corridors which link ports in seven coastal countries (Cote d'Ivoire, Guinea, Ghana, Togo, Senegal, Benin and Nigeria) to three landlock countries (Niger, Burkina Faso and Mali). The West African corridors comprise a network spanning more than $17,000 \mathrm{~km}$ with several transit corridors and a coastal corridor. Similar logistic scenarios are predominant across West and Central Africa some of which include bureaucratic bottlenecks, poor infrastructure, inefficiency and corruption.

Inefficient and high-cost logistics are hindering growth, increasing isolation of landlocked countries, driving up import prices, and reducing export competitiveness in West and Central Africa [21]. These challenges which hamper trade potential and affect the countries' rankings in the Logistics Performance Index (LPI) center around congestion at ports, abysmal conditions of land transit structures and extended delays for cargo processing [17] 
(p. 57). According to the 2018 World Bank LPI rankings, the best ranked country within West and Central Africa (Cote d'Ivoire) comes up at number 50 globally [22], while the other countries rank much lower on the list. Most of these countries have very tedious custom-clearing processes which are inefficient and costly, and road networks which are poorly maintained leading to huge traffic congestions at ports and costly delays.

Of the 4 ports in Cameroon (Douala, Limbe, Kribi and Tiko), the principal port Douala handles about $95 \%$ of imported goods into the country and serves as seaport for landlocked countries which are Chad, Central African Republic and northern Congo-Brazzaville. With regular operations at $80 \%$, it has an annual capacity of about 7 million tons with estimated storage capacity (2014) of over 11 million tons which results in extended vessel and cargo delays of on average 3.4 days [21]. In Nigeria, there are six major ports, three of which are in the crude oil producing regions and mostly support this sector; however, Lagos port is the main entry for most import and export. These ports are considered as the gateways to the nation's economy [22]. The corridor between Abidjan-Lagos is more developed than most other gateway corridors, yet cross-border transactions are limited due to little organization of freight forwarding and customs clearance and freight forwarding between countries along the corridor, inefficient truck sizes transporting goods and Nigerian import restrictions which encourage smuggling between Benin and Nigeria [23] (p. 36). With over $70 \%$ of the West African population, and with $853 \mathrm{~km}$ of the Atlantic Ocean coastline spanning seven states, access to Nigeria's markets presents huge economic potential. Partial privatization and management concessions of seaports has improved overall performance and efficiencies; however, bottlenecks from traffic gridlock, huge trucking activity, multiple checkpoints, corruption and poor customs performance still cause major impediments [24]. Some critical issues affecting logistics in the region include:

- Insecurity and Militancy: Rising cases of kidnapping, terrorism, bombing, sea piracy and militant activities have plagued several parts of this sub-region particularly Nigeria, Cameroon and Mali, making it increasingly unattractive to foreign investments. Logistics operations and costs have significantly increased because of the need for additional security arrangements as well as higher insurance premiums from insurance brokers.

- Information asymmetry: Africa's mobile telecommunications market has seen some level of growth since the early 2000s; however, the continent is still the least connected globally with internet penetration rates of only $25 \%$ compared to the -world average of $54 \%$. In Sub-Saharan Africa, the rates are further lower with 21\% [9]. In addition, while Western economies are adopting $4 \mathrm{G}$ and $5 \mathrm{G}$ technologies, African countries are relying on $2 \mathrm{G}$ and $3 \mathrm{G}$ which have lower network coverage levels. This is attributable to limited telecommunications infrastructure and the unavailability of supporting infrastructure such as stable electricity which greatly increases delivery and operation cost.

- Road network systems in many parts of (West) Africa are dysfunctional due to poor construction, inadequate road maintenance, corruption in allocating budgets, bureaucratic challenges and other hidden costs. In Cameroon, for example, there are 10 times more $\mathrm{km}$ of unpaved roads $(50,000 \mathrm{~km})$ than paved roads $(5000 \mathrm{~km})$ which are poorly maintained, making many routes unpassable during the wet season and resulting in long delays of goods due to truck diversions [23]. This significantly increases transport prices during wet seasons as transporters might refuse to ply certain areas due to bad roads. Road transport in Ghana is significantly better as most of the major cities, towns and villages are linked, effectively connecting agricultural production areas with regional and local markets. Over $97 \%$ of passenger and freight traffic in Ghana is by road [25]. The Cote d'Ivoire's road network is generally considered the best in SSA as it links all the regions and main townships in the country and is well suited for long distance transport.

- Rail systems infrastructure across the sub-region is grossly inadequate, for example in Nigeria, where the existent rail lines are those which were built during the colonial era 
(late-nineteenth century) and are largely dysfunctional. This has added more pressure in traffic volume on the limited road networks available.

- Air transport in West and Central Africa is still considered weak despite recent positive signals in the form of policy mediation, recapitalization and deregulation. In Nigeria, for example, absence of a coherent air transport policy, poor management, obsolete facilities, air crashes and weak security are some of the major challenges facing the airline industry [26]. Ghana has a broader national and international airline network which connects it to the rest of the world and handles the highest volume of cargo in the sub-region. For example, to highlight the outdated systems which serve as impediments to efficiency in the sector, the Republic of the Congo has to obtain overflight and landing clearances-requests that must pass through both the Ministry of Foreign Affairs and the Directorate-General for Strategic Affairs and Military Cooperation (DGASCOM)-before flights are allowed.

- Corruption and Inconsistent Fiscal Policies: Entire economies across West and Central Africa have been severely impacted by inconsistent government policy directions and corruption [27]. The regulatory environment in many parts of SSA, particularly with relation to customs processes, transportation services, logistic infrastructure, is not sufficiently conducive for effective business. There is a policy shift from public-sectormanaged-logistics infrastructure to private-sector-managed infrastructure which has resulted in improvement of the sector; however, uncertainties in policy directions sometimes outweigh these improvements.

- Between Nigeria and Benin, for example, there have been several cross-border restrictions over the last two decades that have significantly disrupted functional supply chains. Port and customs bribery are rife across the sub-region, except for the port of Cote d'Ivoire, leading to increased costs and lead time. According to a 2015 report, it could take up to three months to import auto parts through Port Harcourt in Nigeria compared to South Africa's Durban port which took about one month [28].

\section{South Africa}

South Africa is ranked highest in Africa and 33rd globally in the World Bank's 2018 Logistics performance Index. It is favored as a gateway to the rest of the continent because of its well-integrated intermodal system of transportation which helps to reduce the stress of logistics and improves efficiency. Pressing concerns for logistics in South Africa are the rising costs of transportation, and the increasing cost of operational infrastructure and personnel. It has good infrastructure; however, this is not maintained or extended to meet the demand, and poor operations such as lack of communication between various divisions leads to bad planning, inefficiencies and lack of accountability [29]. As of 2014, the Barloworld Logistics report noted that the topmostsupply chain constraint in South Africa is a shortage of skills-particularly in supply chain, communications and engineering [30].

\section{East Africa}

Logistic infrastructure has improved significantly across some countries in East Africa. For example, Kenya's infrastructure has contributed 0.5 percentage points to annual per capita GDP growth over the last decade, over $90 \%$ of the population now has GSM cell signal access, and a successful public-private partnership has made Kenya's airline a top carrier and key gateway to Africa [31]. The Northern Corridor is the busiest and most important transport route in East and Central Africa, and links the landlocked economies of Rwanda, Burundi, Uganda and Eastern DR Congo to Kenya's Port of Mombasa via a well-connected transport network comprising a road network, railways, inland water routes and container terminals (Inland Container Depots); however, the ports suffer from congestion, inefficient transshipment performance and low container capacity [17]. The Central Corridor linking Dar es Salaam (Tanzania) also serves these landlocked countries.

To summarize, the most critical logistical challenges in Sub-Saharan Africa are shown in Table 1 below. 
Table 1. Table showing Logistic challenges in Sub-Saharan Africa [21].

\begin{tabular}{cll}
\hline Inefficiency & & \multicolumn{1}{c}{ Description } \\
\hline $\begin{array}{c}\text { Gateway } \\
\text { inefficiencies }\end{array}$ & - & $\begin{array}{l}\text { Cheaper demurrage than warehouse storage costs encourage } \\
\text { longer dwell times at ports }\end{array}$ \\
& Cumbersome custom clearance process and lack of single window \\
Poor GPS tracking systems
\end{tabular}

\section{Empirical Investigation via Semi-Structured Interviews}

To substantiate the findings from the systematic literature analysis, semi-structured interviews have been used as they provide a flexible and reciprocal interaction method and are the most widely used form of qualitative research interviews [5]. A structure of questions has been prepared to serve as a guideline for the discussions, all of which has been conducted online due to the COVID-19 pandemic and location differences. Next, the findings from the literature review have been reviewed to enable the author develop confidence in providing impromptu follow-up questions for in-depth analysis during the interview. The proposed questions have been reviewed by a professor to ensure the clarity of the approach, after which semi-structured interviews have been conducted with six logistics service providers in Sub-Saharan Africa.

The selected approach of a semi-structured interview facilitated a dynamic exchange of information between the participants and the interviewer [32] in a bid to obtain an experiential assessment of the current practice of logistics in the region. In addition, based on the subjective nature of the information provided, semi-structured interviews allowed the participants sufficiently to explore the topic under discussion to provide as much relevant feedback as possible. Interviews were conducted with six logistics service providers and professionals. Two of the participants were logistics service providers for retail businesses, one was a last mile delivery professional, one was the founder and $\mathrm{COO}$ of a 3PL company for wholesaling, one was a logistics manager for a freight forwarding company, and one was a logistics manager for a trucking company. All participants and their companies were located in Nigeria, and two of the companies have operations across international supply chains. For the six calls, an average of $23 \mathrm{~min}$ were used for each participant, and all calls were conducted through online Zoom meetings. A cross-section of participants' information is shown in Table 2.

The interview questions have been structured around the findings from the systematic literature review, in an open-ended format which allows participants to provide detailed responses. The first set of questions allowed the participants to describe their level of experience, understanding of digitalization in logistics and type of involvement in logistics alongside their companies. The next set of questions addressed the most common logis- 
tics challenges faced in Sub-Saharan Africa, and asked participants for their experience encountering and working around these challenges. They were asked to describe the consequences for cost, time and quality. The subsequent questions asked them to describe the advantages or disadvantages of adopting digital technologies in the region, the level of adoption currently existent and their plans to include digitalization in their own business activities. An overview of the semi-structured interviews provides Table 3. Based on the semi-structured interviews, the following challenges were identified.

Table 2. Participants interviewed for the study.

\begin{tabular}{|c|c|c|c|c|c|}
\hline Pseudo-Name & Participant Role & Type of Organization & Business Area & Length of Interview & Method \\
\hline Participant A & $\begin{array}{l}\text { Founder/Chief } \\
\text { operating officer }\end{array}$ & 3PL service provider & $\begin{array}{l}\text { Wholesale and } \\
\text { Retail logistics }\end{array}$ & $26 \mathrm{~min}$ & Online \\
\hline Participant B & $\begin{array}{c}\text { Logistics service } \\
\text { provider }\end{array}$ & 3PL service provider & Retail logistics & $25 \mathrm{~min}$ & Online \\
\hline Participant C & $\begin{array}{l}\text { Logistics service } \\
\text { provider }\end{array}$ & 3PL service provider & Retail logistics & $26 \mathrm{~min}$ & Online \\
\hline Participant D & $\begin{array}{l}\text { Logistics service } \\
\text { provider }\end{array}$ & B2C & $\begin{array}{l}\text { Last mile } \\
\text { delivery }\end{array}$ & $20 \mathrm{~min}$ & Online \\
\hline Participant E & Manager & $\mathrm{B} 2 \mathrm{~B}$ & Freight forwarding & $19 \mathrm{~min}$ & Online \\
\hline Participant F & Manager & $\mathrm{B} 2 \mathrm{~B}$ & Trucking/Haulage & $20 \mathrm{~min}$ & Online \\
\hline
\end{tabular}

\section{(a) Human Resources:}

The ramifications of inadequate workers' skills and the effect it has on logistics 4.0 adoption has been classified as the biggest challenge by the participants. Four of the 6 participants ranked this as the most significant challenge they face in their business, while all participants emphasized thorough digital literacy training for logistics players in the region. Many supply chain workers in Sub-Saharan Africa lack digital skills. According to the participants, the consequences of unskilled labor range from poor quality service delivery, inefficient time management, increased costs on each job to increased human error. Not only is there need for digital literacy, worker integrity and professionalism were also noted. For instance, participant $\mathrm{F}$ (a manager) spoke about how truck drivers used to carry illegitimate cargo alongside company orders in a bid to make personal gains. The drivers would then either switch off their mobile devices or claim to be stuck in traffic, while they completed unauthorized jobs. This results in compromised deliveries and overall inefficiencies.

Immediate digital solutions to these sorts of challenges include use of GPS tracking devices on vehicles, weight trackers for trucks, container tracking and so on; however, these are yet to be adopted. Participant A described how the vast majority of truck owners and drivers were elderly males or illiterate young men who had taken up the job due to economic hardships. Most of them are stuck in their traditional ways and are hesitant to learn and utilize basic technology solutions like location maps, mobile portal systems, operation management tools, and so on. They would rather continue to use paper records, ask for oral description of delivery locations and receive cash transactions. This is a very inefficient system. Human capital training is therefore critical. 
Table 3. Semi-structured interview questions presented to participants.

\begin{tabular}{|c|c|c|c|c|c|c|}
\hline $\begin{array}{c}\text { Participant } \\
\text { (Pseudo-Name) }\end{array}$ & $\begin{array}{c}\text { Definition of } \\
\text { Digitalization in Logistics }\end{array}$ & $\begin{array}{l}\text { Identified Weaknesses of } \\
\text { Logistics in Sub-Saharan Africa }\end{array}$ & $\begin{array}{l}\text { Consequences for Cost, } \\
\text { Time and Quality }\end{array}$ & $\begin{array}{l}\text { How Digitalization can } \\
\text { Impact Logistics }\end{array}$ & $\begin{array}{l}\text { Challenges to Adoption of } \\
\text { Digitalization in Logistics }\end{array}$ & $\begin{array}{c}\text { Plans to Implement } \\
\text { Digitalization in Own Business }\end{array}$ \\
\hline A & $\begin{array}{l}\text { The use of digital } \\
\text { technologies to } \\
\text { simplify, automate } \\
\text { and monitor logistics } \\
\text { processes }\end{array}$ & $\begin{array}{ll}\text { - } & \text { Basic infrastructure } \\
- & \text { Inadequate worker skills } \\
- & \text { Unfavorable regulatory } \\
& \text { framework }\end{array}$ & $\begin{array}{ll}\text { - } & \text { Loss of potential } \\
\text { private capital } \\
\text { investment } \\
\text { - } & \text { Slow processes } \\
- & \text { Several untapped } \\
\text { markets }\end{array}$ & $\begin{array}{ll}\text { - } & \text { Faster and more } \\
\text { seamless processes } \\
\text { - } & \text { More capital } \\
\text { investments and } \\
\text { new business } \\
\text { opportunities } \\
\text { Improved } \\
\text { efficiencies }\end{array}$ & $\begin{array}{ll}\text { - } & \text { Potential } \\
\text { cyber-attacks/security risks } \\
\text { Heavy investments in } \\
\text { existent infrastructure e.g., } \\
\text { fleets of manual trucks, }\end{array}$ & $\begin{array}{l}\text { Currently developing a } \\
\text { mobile app for trucking } \\
\text { business to digitally connect } \\
\text { truck drivers to jobs (similar } \\
\text { to Uber model for } \\
\text { passenger transportation) }\end{array}$ \\
\hline B & $\begin{array}{l}\text { The use of technology } \\
\text { to handle different } \\
\text { processes in } \\
\text { logistics-order } \\
\text { placements, bookings, } \\
\text { payments, customs, } \\
\text { tracking, etc. }\end{array}$ & $\begin{array}{l}\text { - Manual processes make it } \\
\text { difficult to scale } \\
\text { Too many regulators and } \\
\text { corrupt practices } \\
\text { Weak/loop-holed systems } \\
\text { - } \quad \text { g., financial payments }\end{array}$ & $\begin{array}{l}\text { High costs of } \\
\text { maintenance of } \\
\text { faulty equipment } \\
\text { (damaged due to } \\
\text { bad infrastructure } \\
\text { e.g., bad roads) }\end{array}$ & $\begin{array}{ll}\text { - } & \text { It makes logistics } \\
\text { easier by } \\
\text { automating } \\
\text { processes } \\
\text { - } \quad \text { It allows more } \\
\text { flexibility } \\
\text { - } \quad \text { Provides } \\
\text { data-driven } \\
\text { customer insights }\end{array}$ & $\begin{array}{l}\text { Lack of enabling } \\
\text { environment (policies, } \\
\text { regulations, financing, etc.) }\end{array}$ & \\
\hline C & $\begin{array}{l}\text { A way to automate } \\
\text { transportation in } \\
\text { logistics, eliminate } \\
\text { manual and paper } \\
\text { processes using } \\
\text { digital solutions }\end{array}$ & $\begin{array}{ll}\text { - } & \begin{array}{l}\text { Difficulty in tracking } \\
\text { orders and deliveries, }\end{array} \\
\text { truck drivers } \\
\text { Terrible access to ports } \\
\text { and poor turnaround time } \\
\text { - } \quad \text { Corruption } \\
\text { - } \quad \text { Lack of real-time } \\
\text { information }\end{array}$ & $\begin{array}{l}\text { Inflation of prices } \\
\text { of goods from lack } \\
\text { of efficient logistics } \\
\text { systems }\end{array}$ & $\begin{array}{ll}\text { - } & \begin{array}{l}\text { Tracking of location } \\
\text { and weight of } \\
\text { trucks/deliveries }\end{array} \\
\text { - } & \text { Financial solutions } \\
\text { e.g., digitized } \\
\text { payments, access to } \\
\text { financing } \\
\text { Better customer } \\
\text { experience }\end{array}$ & $\begin{array}{ll}\text { - } & \begin{array}{l}\text { Excessive bureaucracy and } \\
\text { numerous bottlenecks in the }\end{array} \\
\text { system } \\
\text { Poor awareness of } \\
\text { digitalization benefits } \\
\text { among demographics } \\
\text { - Bad infrastructure }\end{array}$ & $\begin{array}{l}\text { Developing mobile app to } \\
\text { monitor truck driver } \\
\text { operations by tracking } \\
\text { weight and location of } \\
\text { trucks in real time }\end{array}$ \\
\hline
\end{tabular}


Table 3. Cont.

\begin{tabular}{|c|c|c|c|c|c|c|}
\hline $\begin{array}{c}\text { Participant } \\
\text { (Pseudo-Name) }\end{array}$ & $\begin{array}{c}\text { Definition of } \\
\text { Digitalization in Logistics }\end{array}$ & $\begin{array}{l}\text { Identified Weaknesses of } \\
\text { Logistics in Sub-Saharan Africa }\end{array}$ & $\begin{array}{l}\text { Consequences for Cost, } \\
\text { Time and Quality }\end{array}$ & $\begin{array}{l}\text { How Digitalization can } \\
\text { Impact Logistics }\end{array}$ & $\begin{array}{l}\text { Challenges to Adoption of } \\
\text { Digitalization in Logistics }\end{array}$ & $\begin{array}{c}\text { Plans to Implement } \\
\text { Digitalization in Own Business }\end{array}$ \\
\hline $\mathrm{D}$ & $\begin{array}{l}\text { Technology } \\
\text { improvements which } \\
\text { support businesses in } \\
\text { their logistics } \\
\text { operations }\end{array}$ & $\begin{array}{ll}- & \text { Untapped markets } \\
- & \text { Low visibility } \\
- & \text { Insecurity } \\
- & \text { Low innovation using } \\
& \text { manual systems }\end{array}$ & $\begin{array}{l}\text { High operational } \\
\text { costs }\end{array}$ & 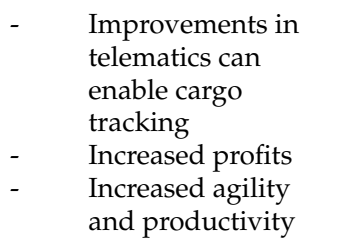 & $\begin{array}{l}\text { Low awareness of } \\
\text { digitalization } \\
\text { Poor incentives from } \\
\text { government for } \\
\text { digitalization }\end{array}$ & \\
\hline $\mathrm{E}$ & $\begin{array}{l}\text { The use of digital } \\
\text { technologies to } \\
\text { optimize the } \\
\text { transportation and } \\
\text { delivery of goods and } \\
\text { services from } \\
\text { producers to } \\
\text { end-users. }\end{array}$ & $\begin{array}{ll}- & \text { Infrastructural decay } \\
- & \text { Poor access to finance for } \\
\text { new players } \\
\text { - } & \text { Unregulated pricing for } \\
& \text { logistics service providers }\end{array}$ & $\begin{array}{ll}\text { - } & \text { Poor customer } \\
\text { service quality } \\
\text { - } & \text { High cost }\end{array}$ & $\begin{array}{ll}\text { - } & \text { Access to } \\
\text { underserved } \\
\text { markets } \\
\text { Improved visibility } \\
\text { and integration of } \\
\text { information/data } \\
\text { Reliable and } \\
\text { efficient services }\end{array}$ & $\begin{array}{l}\text { Poor internet penetration } \\
\text { across the market }\end{array}$ & $\begin{array}{l}\text { Developing digital solution } \\
\text { to provide training and } \\
\text { financial support to } \\
\text { entrepreneurs who want to } \\
\text { start a logistics business. }\end{array}$ \\
\hline $\mathrm{F}$ & $\begin{array}{l}\text { Application of digital } \\
\text { solutions to create } \\
\text { new business models } \\
\text { for logistics } \\
\text { businesses }\end{array}$ & $\begin{array}{ll}\text { - } & \text { Inability to reach } \\
\text { underserved areas due to } \\
\text { bad infrastructure } \\
\text { - } \quad \text { Poor systems at ports } \\
\text { - } \quad \text { Bad roads }\end{array}$ & 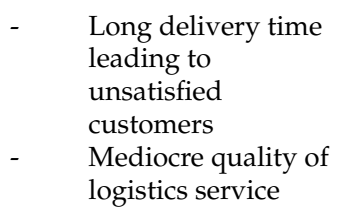 & $\begin{array}{ll}\text { - } & \text { Provide access to } \\
\text { more jobs } \\
\text { - } & \text { Growth in retail } \\
\text { delivery systems } \\
\text { - } \quad \begin{array}{l}\text { Increased profit } \\
\text { margins }\end{array}\end{array}$ & $\begin{array}{l}\text { Low incentives from } \\
\text { government } \\
\text { Inflation which discourages } \\
\text { capital investment in } \\
\text { digitalization }\end{array}$ & $\begin{array}{l}\text { Plan to digitize fleet of } \\
\text { trucks with GPS tracking } \\
\text { systems } \\
\text { Mobile app to aggregate } \\
\text { entire haulage operations } \\
\text { across supply chain }\end{array}$ \\
\hline
\end{tabular}


(b) Institutional framework and Regulation

Most participants spoke of a difficult business environment across the Sub-Saharan Africa region with unfavorable policies which especially affect smaller logistics businesses. This has a significant negative impact on investment flows as investors have doubts despite the massive potential opportunities. Participants B and C especially complained about insensitive policies being enforced for dispatch riders in Nigeria. For instance, in Lagos, licensing fees range from USD 645 for SMEs like restaurants up to USD 51,000 for international courier companies [33], which are being enforced by a specialized arm of the Nigerian Postal Service (NIPOST) which is also a player in the industry. Another policy mentioned was the ban of commercial motorcycles in Lagos, which has been long used as an alternative to the bad roads and traffic-congestion prevalent in the state. Participant $\mathrm{C}$ noted that this single policy affected several logistics micro-businesses and SMEs operating in the state.

Other challenges include exorbitant tariffs, lack of transparency and overly bureaucratic procedures that stifle trade, particularly, intra-regionally. Participant E discussed extensively the challenges to access ports. There is entry and exit regulation at ports that is very cumbersome, a lack of automation and various amateur/unofficial controllers such as trade union officials who extort money from cargo carriers. This results in the popular crisis of congestion of heavy-duty trucks around ports.

\section{(c) Infrastructure}

Weak, and sometimes absent, basic infrastructure is one of the most crucial constraints to economic development in Sub-Saharan Africa. Logistics systems inefficiencies are among the highest in the region due to a lack of enabling infrastructure, which results in inflated prices and higher costs of doing business. For example, transport costs are exceptionally high in African countries, with shipping costs up to two to three times more expensive in landlocked countries than coastal countries, exacerbated by deplorable road conditions and inaccessible roads [34]. One study has shown that poor infrastructure is the main problem in Sub-Saharan Africa and accounts for up to half the cost of transport in intra-regional trade [35].

These process inefficiencies which are major logistics challenges show up in forms of poor structure and organization in the moving of goods, unstructured formats among different actors (cargo recipient, truck driver, truck owner, cargo owner), manual procedures (manual supervision of cargo, paper documentation, etc.) and deadhead trucking (a process whereby a truck returns empty after making a drop-off), all of which are commonplace. Participant F noted that many truck drivers will usually reject smaller one-way jobs, especially when there is no return order as that would result in deadhead trucking, which is highly inefficient. This is made worse due to numerous checkpoints where officials extort bribes from drivers to avoid them being delayed. This also contributes to the high cost of doing business and reduces the efficiency of the trucks. Participant B also mentioned poor city mapping with non-standardized addresses for several rural areas and an absence of postal codes as another factor that makes deliveries difficult in these areas.

Rail transportation (especially for cargo) across several parts of the region is mostly non-existent, despite the fact that rail is one of the most efficient cargo logistics systems in developed countries. Air transportation is expensive, and mostly cost-inefficient for SMEs. Non-existence of rail transport and the cost of air transport leaves road transport as the only practicable alternative in most countries in Sub-Saharan Africa, many of which are landlocked. This has placed immense pressure on road networks, coupled with very poor maintenance cultures resulting in terrible roads conditions which characterize many regions across SSA [26].

These roads are usually filled with gigantic potholes sometimes covered in mud causing breakdown of trucks stuck in them, resulting many times in severe traffic situations. Traffic situations lead to costly downtimes and sometimes entire losses (such as in the case of logistics for perishable commodities). These situations cause truck drivers to avoid certain 
routes, thereby making especially rural communities inaccessible and thereby cutting them off from regional markets and supply chains.

There is also the issue of monopolies being created due to bottlenecks in logistics across the region, which allows bigger players to grab a larger market share since they can pay their way through bottlenecks and stringent regulations which hinder smaller players. When these bottlenecks are removed, more manufacturers and suppliers can deliver more products to the market which will eliminate monopoly of the market which is being created by bigger players and companies. Enabling easier and cheaper logistics will allow smaller players to participate and compete effectively.

(d) Information asymmetry and lack of visibility

Lack of (relevant, real-time) information and data is a significant disadvantage in today's highly volatile supply chain. Many suppliers and supply chain stakeholders in SubSaharan Africa often operate with insufficient knowledge of the market, thereby causing them to make sub-optimal decisions. Participant D emphasized the lack of real-time information as a significant challenge to efficiency in his business as a last-mile delivery service provider. Various issues such as poor city planning, inefficient policing and tracking systems mean that if the address is not readily located, or the customer is not present to receive their delivery, then the service provider has to find a way to communicate with them or return with the package-resulting in sunken costs.

\section{Discussion}

Digitalization is only effective when the basic infrastructure to support it is put in place. For example, the electrification rate across Sub-Saharan Africa remains at about $46.75 \%$ as at 2021, with 600 million people having no access to electricity [36]. Countries such as Nigeria, Ethiopia, Tanzania, Uganda and DR Congo still have very poor electrification rates with more than half of the population being underserved. It is therefore quite impracticable to pursue digital transformation when basic electricity is not available. In this respect, a push for digitalization would be a misplacement of priorities.

When participants in the interviews were asked about their plans to implement digitalization in their own business, it was readily seen that the focus is on developing tracker systems or mobile apps to monitor personnel professional activities, or to aggregate operational activities. These further indicate where the primary pain-points of entrepreneurs and businesses in the region are-Workforce and Information sharing.

Therefore, the following recommendations are provided:

(a) Human capital training

As noted in the interviews, one of the biggest challenges faced by logistics managers and professionals is the level of skill and professionalism of their workers. Digital technologies like educational digital platforms, mobile applications, augmented reality applications, can be used to provide quality teachings, fast-track learning and provide real-time guidance for activities such as in fulfilment centers, warehouses, mechanical repair for truck drivers in transit, etc. There are several possible applications of this, and the benefits of $\mathrm{AR}$ and VR are mostly related to fast knowledge transfer to users, utilizing little to no paper documentation, creating more just-in-time and immersive work instructions since there is less predisposition to retaining knowledge, all of which fosters implementation of innovation.

\section{(b) Institutional framework}

Digitizing the systems required for logistics operations such as registration, financial payments, clearance and forwarding, and so on, will significantly reduce the overly bureaucratic systems, and lead to greater levels of efficiency and transparency, and will boost investor confidence and ease to enter the business. Up to $108 \mathrm{~h}$ needed for export border compliance in the region-about 3 and 7 times more than in emerging and developed economies, respectively [3] (p. 18)—can be saved by automating systems and procedures resulting in faster processing times. 
There are some examples of young startup companies that have begun to implement strategies to integrate logistic activities within African markets, by creating digital logistics platforms that aggregate end-to-end haulage operations and provide collaboration and centralized information for efficient logistics. These include Trella and Kobo 360 [37,38]. However, these improvements need to be incorporated in public and governmental institutions as well.

\section{(c) Visibility and Information Sharing}

Information sharing is now a critical asset among supply chain partners and organizations as the factors responsible for creating value are shifting towards intangible assets today rather than financial or physical assets. Mobile technologies and access to internet provides supply chain actors with real-time information enabling them to make optimal business, thereby facilitating improved efficiency and potential gains. Cloud Computing Technologies and Supply Chain Portals also provide information sharing capabilities to various actors simultaneously thereby optimizing supply chain effectiveness and creating new business models.

Transparency of systems and processes is very important in developing efficient markets, thus creating an integrated platform for management of demand and supply will improve supply chain performance in SSA drastically. Supplier Collaboration Portals are a good example of how digitalization can help to consolidate supplier data, provide supplier collaboration tools and effectively manage supplier relationships. This will significantly improve efficiency across supply chains in SSA and strengthen logistics. It will also help to solve the prevalent lack of access to relevant information among many players across the supply chain.

\section{(d) Infrastructure (Leapfrog development)}

The lack of adequate infrastructure in SSA countries to date does present a striking opportunity for this region to develop. Traditional theories of development postulate that for nations to become wealthier, they have to follow the tracks of developed nations in a sort of sequential manner [39] (p. 148). However, the low level of investment in legacy infrastructure by African countries allows these developing countries to bypass traditional intermediate infrastructure stages of the industrial age and paths to development and take advantage of new digital infrastructure and data governance systems which are significantly more advanced. This concept, known as leapfrog development or leapfrogging, could enable countries to skip stages of development and explore the latest technologies which have new opportunities that could be path creating.

A popular example is the mobile phone revolution across Africa, which bypassed much of the use of landline infrastructure and gave millions of people access to mobile technology. This also revolutionized financial systems with the introduction of digital banking and mobile payment systems (e.g., M-Pesa in Kenya). As a result, many other emerging economies in Africa have a broader access to financial services through several forms of mobile banking and digital payment systems without having gone through much of the credit-card based systems which still dominate financial payments in developed economies. This concept can also significantly impact logistics systems in SSA, such that several types of services can be provided with comparatively lower physical infrastructure requirements and costs of investment. These include:

- Off-grid solar and alternative energy

- Wireless satellite bandwidth

- Mobile technology solutions

- Logistics delivery systems, e.g., drones

- Educational infrastructure such as e-learning, and so on.

One study conducted a spatial network analysis to identify a feasible road network that could connect all capitals of countries in Sub-Saharan Africa and cities with over 500,000 population. The results of that simulation showed that if the road could be constructed to barely operate at 'functioning' levels, an up to USD 250 billion increase in 
trade over land could be attained [40]. Overall, digital technology solutions will provide opportunities for these developing countries to attempt to catch up to the latest levels of service quality in logistics and supply chain management.

\section{(e) Regulation and Policies}

Government policies and regulation can have a symbiotic effect with adoption of digital technologies. While governments can either provide enabling environments which allow the adoption and free use of digital technologies or stifle development through their policies, digital technologies with solid use cases can also influence the direction of regulation and approach to policies which the government will decide to use.

A good example is the M-PESA mobile money payment system of Kenya. The Government that came into power in Kenya in 2003 wanted to reverse the recession between 1995-2002, and so developed an economic recovery blueprint for inclusive growth in the financial sector [41]. Kenyans started trading with airtime in 2002 by buying bulk airtime in scratch cards, and slicing into smaller units to sell, share with relatives and friends, or resolve debts. By 2005, Safaricom conducted actual research on the product and when the potential for success was realized, it became obvious that there were pieces of legislationmicro finance bill, company law, communication law, etc.- that were needed to push the financial sector towards the next level [41]. The massive success of M-PESA has been facilitated by good policies and regulations and has also influenced other policies in areas where the possibility for growth and development was made obvious by the M-PESA success.

Once the potential for tangible efficiency improvements from digital technologies can be seen (from research studies, other countries' successes, etc.), governments of developing countries in Sub-Saharan Africa would be urged to make necessary policy adjustments which will support the adoption of these technologies.

\section{Outlook and Limitations}

As shown in the preceding sections, several logistics challenges still exist in SSA making the region lag significantly behind many parts of the world. While some countries are performing relatively strong, such as South Africa, which is rated to have a better transport infrastructure systems than some other fast-developing economies such as Indonesia, other countries in the region are not performing nearly as strong. The demand for Africa's raw commodities and its expanding markets show that the continent cannot be ignored any longer, and the supply chain and logistics market is growing at a fast pace.

With the recently commenced African Continental Free Trade Area (AfCFTA) agreement, which seeks to create a single market for goods and services across Africa by providing a mutually beneficial and comprehensive agreement among the member states, the opportunities for the logistics industry across Sub-Saharan Africa are massive. By lowering the trade barriers and facilitating more intra-regional trade, more and more logistics companies and service providers will seek to participate in the market, which has huge opportunities for growth and revenue. Capital investments flow will therefore see a significant increase as more and more investors will be willing to participate in the single largest free trade area in the world.

There are still so many underserved communities in SSA and therefore lots of room for expansion. Foreign governments and State-Owned Enterprises have been investing financially in massive projects, particularly, in SSA in exchange for raw materials and commodities. Several ports are being constructed or expanded to serve as gateways that will connect Africa to the rest of the world. Five of these include Lekki in Nigeria, Musoma in Tanzania, Lamu in Kenya, Lobito and Barra do Dande in Angola. Countries like Ghana, Nigeria and Kenya are favorite entries into the African market for international investors as they have large markets with a rapidly increasing middle-class [3].

Retail growth is driving much of the growth in SSA, which is subsequently developing the transport and logistics industry. Moreover, as a result of the pandemic, digital shopping has significantly increased within many African countries with increased percentage share 
of consumers shopping online of up to $81 \%, 79 \%$ and $72 \%$ in Nigeria, Kenya and Tanzania, respectively [42]. The logistics industry is already in an upward trend and is expected to grow significantly over the next decade.

Leapfrog development does indeed pose great potential especially for Africa, with several countries proving to be more open to new technologies and being innovative. In terms of drone usage, for example, African countries are leading the way, using drones in tourism, e-commerce and health services. A good example is the case of the first commercial drone delivery service in the world, Zipline, which began its operations in Rwanda and now delivers blood by drone to almost half of all the blood transfusion centers in Rwanda using orders made online via text, phone or WhatsApp [43].

Digitalization in logistics is going to play a very notable role in the facilitation of trade and logistics expansion and penetration across Sub-Saharan Africa. Technologies such as drones, mobile banking, tracker systems, digitized trucks for efficient transport and cold chain, digital platforms for supplier collaboration, robots, AR and VR for educational and operational purposes will boost the gains made by AfCFTA and support the proper servicing of the entire African market. Some technologies have already been tested, are in use and are successful, such as mobile payments (M-PESA), drone deliveries (Zipline), big data for end-to-end haulage (Kobo360) and so on. Digitalization will also facilitate automation across several parts of the supply chain, eliminating routine, low skill tasks, and will create new and advanced job opportunities across training and development, skilled workforce and new market openings, which will require a skilled workforce with higher pay, better conditions and an improved standard of living.

There will also be lots of jobs created and work skills trainings available over the next few years to fill the existing gaps in logistics created by the expanding markets. Several companies operating in SSA are already focusing on training and skills development for workers across the region.

One limitation of this study is that only a comprehensive literature review and small sample of participants interviewed have provided the information for this work. Another challenge is the paucity of published information on the implementation of digital technologies in the region. Only publications in English from the databases used (Science Direct and WebOfScience) were considered, and only one individual — the author-performed the literature cleanse process to identify relevant literature.

Subsequent research could conduct more elaborate surveys involving more participants and field interviews to obtain a broader amount of business data from companies and businesses in the logistics sector and undergoing digital transformation in the region. They can also follow up on the progress from developments such as regulatory changes, removal of trade and non-trade barriers, private investments, which would arise from the signed AfCFTA agreement.

\section{Conclusions}

This paper highlights the challenges faced in logistics across Sub-Saharan Africa, and the potential for digitalization to facilitate growth and development particularly with regard to trade. Logistic challenges in Sub-Saharan Africa have been shown to have a crippling effect on economic development despite the massive potential of the continent which has a huge population and numerous natural and mineral resources.

A comprehensive literature analysis was conducted on literature majorly from two databases-Web of Science and Science Direct. The purpose of the search was to identify publications that address the potential effects of digitalization on logistics in Sub-Saharan Africa. A total of 287 publications were considered relevant. A majority of publications were focused on the logistics of specific commodities between rural and urban communities; however, over the last few years, research interest in the field has been growing rapidly. Semi-structured interviews were also conducted with logistics service professionals to identify the practical challenges as well as the potential for digitalization. 
The study has shown that by eliminating the bottlenecks in logistics, more suppliers will be able to deliver more products which will eliminate monopoly situations which exist across industries. The application of digital technologies particularly in logistics is beneficial for improved speed, efficiency, transparency and will enable expansion and penetration to the underserved communities within the region. It will allow countries across SSA to leapfrog development and also greatly support job creation and trade facilitation in tandem with the AfCFTA agreement which is enabling intra-regional trade across the world's largest free trade area.

Author Contributions: Conceptualization, D.K. and H.W.; methodology, D.K. and H.W.; validation, H.W.; formal analysis, D.K.; investigation, D.K.; writing-original draft preparation, D.K.; writingreview and editing, H.W. All authors have read and agreed to the published version of the manuscript.

Funding: This research received no external funding.

Institutional Review Board Statement: Not applicable.

Informed Consent Statement: Not applicable.

Data Availability Statement: Not applicable.

Conflicts of Interest: The authors declare no conflict of interest.

\section{References}

1. Chavarria-Barrientos, D.; Batres, R.; Wright, P.K.; Molina, A. A methodology to create a sensing, smart and sustainable manufacturing enterprise. Int. J. Prod. Res. 2018, 56, 584-603. [CrossRef]

2. Buyokozkan, G.; Gocer, F. Digital Supply Chain: Literature review and a proposed framework for future research. Comput. Ind. 2018, 97, 157-177. [CrossRef]

3. Adewole, A.; John, J.S. Logistics and Global Value Chains in Africa: The Impact on Trade and Development; Palgrave Macmillan: London, UK, 2019; p. 18.

4. Buys, P.; Dasgupta, S.; Thomas, T.S.; Wheeler, D. Determinants of a Digital Divide in sub-Saharan Africa: A spatial econometric analysis of cell phone coverage. World Dev. 2009, 37, 1494-1505. [CrossRef]

5. DiCicco-Bloom, B.; Crabtree, B.F. The qualitative research interview. Med. Educ. 2006, 40, 314-321. [CrossRef] [PubMed]

6. Ivanov, D.; Tsipoulanidis, A.; Schönberger, J. Digital supply chain, smart operations and Industry 4.0. In Global Supply Chain and Operation Management: A Decision-Oriented Introduction to the Creation of Value; Springer International Publishing: Cham, Switzerland, 2019; pp. 481-526.

7. Souza, G.R.; Valamede, L.S.; Akkari, A.C.S. Characterization of Digital Supply Chain. In Brazilian Technology Symposium; Springer International Publishing: Cham, Switzerland, 2020; pp. 41-47.

8. Oyedijo, A.; Adams, K.; Koukpaki, S. Supply chain management systems in Africa: Insights from Nigeria. In Business in Africa in the Era of Digital Technology; Springer International Publishing: Cham, Switzerland, 2021; pp. 121-140.

9. World Bank Group. Future of Food: Harnessing Digital Technologies to Improve Food System Outcomes; World Bank: Washington, DC, USA, 2019; pp. 4-28.

10. World Bank. Nigeria: Food Smart Country Diagnostic; World Bank: Washington, DC, USA, 2020; pp. 8-26. Available online: https:/ / openknowledge.worldbank.org/handle/10986/31565 (accessed on 13 July 2021).

11. World Bank. The African Continental Free Trade Area: Economic and Distributional Effects; World Bank: Washington, DC, USA, 2020; Available online: https:/ / openknowledge.worldbank.org/handle/10986/34139 (accessed on 2 July 2021).

12. Parker, H.; Luiz, J.M. Designing supply chains into Africa: A South African retailer's experience. In Supply Chain Design and Management for Emerging Markets: Learning from Countries and Regions; Springer International Publishing: Cham, Switzerland, 2015; pp. 60-83.

13. Takele, T.B. The relevance of coordinated regional trade logistics for the implementation of regional free trade area of Africa. JTSCM 2019, 13, 1-11. [CrossRef]

14. Overseas Development Institute. Impediments to Intra-Regional Trade in Sub-Saharan Africa. Available online: https://odi.org/ en/publications/impediments-to-intra-regional-trade-in-sub-saharan-africa/ (accessed on 5 July 2021).

15. Matthee, M.; Naude, W. Export diversity and regional growth: Empirical evidence from South Africa. In WIDER Research Paper NO. 2007/11; The United Nations University World Institute for Development Economics Research (UNU-WIDER): Helsinki, Finland, 2007; p. 1.

16. Alexander, C.; Warwick, K. Governments, exports, and growth: Responding to the challenges and opportunities of globalization. World Econ. 2007, 30, 177-194. [CrossRef]

17. Muogboh, O.S.; Ojadi, F. Indigenous logistics and supply chain management practice in Africa. In Indigenous Management Practices in Africa; Advanced Series in Management; Emerald Publishing Limited: Bingley, UK, 2018; Volume 20, pp. 47-70. [CrossRef]

18. Reuters. Available online: https://www.reuters.com/article/us-nigeria-inflation-idUSKBN1XS2D3 (accessed on 3 July 2021). 
19. Page, J.; Tarp, F.; Rand, J.; Shimeles, A.; Newman, C.; Soderbom, M. Manufacturing Transformation: Comparative Studies of Industrial Development in Africa and Emerging Asia; Oxford University Press: Oxford, UK, 2016.

20. Teravaninthorn, S.; Raballand, G. Transport Prices and Costs in Africa: A Review of the International Corridors; World Bank/The International Bank for Reconstruction and Development: Arlington, VA, USA, 2009; pp. 13-44.

21. Nathan Associates Inc. Logistics Cost Study of Transport Corridors in Central and West Africa; Nathan Associates: Washington, DC, USA, 2017.

22. Jaja, C. Port development in Nigeria: Trends and patterns. J. Transp. Secur. 2009, 2, 107. [CrossRef]

23. World Bank. International LPI Global Rankings. 2018. Available online: https://lpi.worldbank.org/international/global (accessed on 17 July 2021).

24. Nigeria Port Assessment. Available online: https://dlca.logcluster.org/display/public/DLCA/2.1+Nigeria+Port+Assessment (accessed on 19 July 2021).

25. Ghana Road Network. Available online: https://dlca.logcluster.org/display/public/DLCA/2.3+Ghana+Road+Network (accessed on 19 July 2021).

26. Faajir, A.; Zidan, Z.H. An analysis of the issues and challenges of transportation in Nigeria and Egypt. Bus. Manag. Rev. 2016, 7, 5 .

27. Osabiyi, K.E.; Oladipo, A.O.; Olofin, O.P. Corruption, institutional quality, and economic growth in west African countries (1995-2017). J. Public Adm. Gov. 2019, 9, 217-229.

28. Winning Supply Chain Strategies for African Markets. Available online: https://www.supplychainquarterly.com/articles/948winning-supply-chain-strategies-for-african-markets (accessed on 17 July 2021).

29. Badenhorst-Weiss, J.A.; Waugh, B.J. A logistics sector's perspective of factors and risks within the business environment that influence supply chains' effectiveness: An explorative mixed method study. JTSCM 2015, 9, 177. [CrossRef]

30. Barloworld Logistics. The Rise and Fall of Customers and Companies; Barloworld Logistics: Doringkloof, South Africa, $2014 ; \mathrm{p} .16$.

31. Kenya Logistics Infrastructure. Available online: https://dlca.logcluster.org/display/public/DLCA/2+Kenya+Logistics+ Infrastructure (accessed on 23 July 2021).

32. Kvale, S. Interviews: An Introduction to Qualitative Research Interviewing; Sage Publications, Inc.: Thousand Oaks, CA, USA, 1994.

33. Techpoint.africa. Besides Licence Fees, Nigerian Logistics Players to Remit $2 \%$ of Their Annual Revenues. Available online: https: / techpoint.africa/2020/07/28/license-ngeria-nipost-logistics/ (accessed on 9 December 2021).

34. Eifert, B.; Gelb, A.; Ramachandran, V. The cost of doing business in Africa: Evidence from enterprise survey data. World Dev. 2008, 36, 1531-1546. [CrossRef]

35. Limao, N.; Venables, A.J. Infrastructure, geographical disadvantage, transport costs and trade. World Bank Econ. Rev. 2001, 15, 451-479. [CrossRef]

36. Rural Electrification. Available online: https:/ / www.ruralelec.org/rural-electrification (accessed on 15 July 2021).

37. Trella. Available online: https://www.trella.app/ (accessed on 13 July 2021).

38. Kobo 360. Available online: https:/ / www.kobo360.com/NG/en/ (accessed on 13 July 2021).

39. Burkett, P.; Hart-Landsberg, M. A critique of "catch-up" theories of development. J. Contemp. Asia 2003, 33, 147-171. [CrossRef]

40. Buys, P.; Deichmann, U.; Wheeler, D. Road Network Upgrading and Overland Trade Expansion in Sub-Saharan Africa. Policy Research Working Paper No. 4097; World Bank Publications: Washington, DC, USA, 2006.

41. Ndung'u, N.S. A Digital Financial Services Revolution in Kenya: The M-Pesa Case Study; African Economic Research Consortium: Nairobi, Kenya, 2021; pp. 23-44.

42. Share of Consumers Shopping More Online since the Beginning of the Coronavirus (COVID 19) Pandemic in Selected African Countries in 2021. Available online: https:/ / www.statista.com/statistics/1233745/share-of-consumers-shopping-more-onlinedue-to-covid-19-in-selected-african-countries / (accessed on 10 November 2021).

43. Logistics Update Africa. Available online: https://www.logupdateafrica.com/africa-the-future-is-now-logistics (accessed on 19 November 2021). 